\title{
Nanofibrous solid dosage form of living bacteria prepared by electrospinning
}

\author{
Zs. K. Nagy ${ }^{1}$, I. Wagner ${ }^{*}$, Á. Suhajda ${ }^{2}$, T. Tobak ${ }^{1}$, A. H. Harasztos ${ }^{2}$, T. Vigh ${ }^{1}$, P. L. Sóti ${ }^{1}$, \\ H. Pataki ${ }^{1}$, K. Molnár ${ }^{3,4}$, Gy. Marosi ${ }^{1}$ \\ ${ }^{1}$ Budapest University of Technology and Economics, Department of Organic Chemistry and Technology, 1111 Budapest, \\ Budafoki út 8., Hungary \\ ${ }^{2}$ Budapest University of Technology and Economics, Department of Applied Biotechnology and Food Science, 1111 \\ Budapest, Szent Gellért tér 4., Hungary \\ ${ }^{3}$ Budapest University of Technology and Economics, Department of Polymer Engineering, 1111 Budapest, Müegyetem \\ rkp. 3., Hungary \\ ${ }^{4}$ MTA-BME Research Group for Composite Science and Technology, 1111 Budapest, Múegyetem rkp. 3., Hungary
}

Received 9 October 2013; accepted in revised form 27 December 2013

\begin{abstract}
The aim of this work was to investigate the suitability of electrospinning for biodrug delivery and to develop an electrospinning-based method to produce vaginal drug delivery systems. Lactobacillus acidophilus bacteria were encapsulated into nanofibers of three different polymers (polyvinyl alcohol and polyvinylpyrrolidone with two different molar masses). Shelf life of the bacteria could be enhanced by the exclusion of water and by preparing a solid dosage form, which is an advantageous and patient-friendly way of administration. The formulations were stored at $-20,7$ and $25^{\circ} \mathrm{C}$, respectively. Viability testing showed that the nanofibers can provide long term stability for huge amounts of living bacteria if they are kept at (or below) $7^{\circ} \mathrm{C}$. Furthermore, all kinds of nanowebs prepared in this work dissolved instantly when they got in contact with water, thus the developed biohybrid nanowebs can provide new potential ways for curing bacterial vaginosis.
\end{abstract}

Keywords: nanomaterials, electrospinning, vaginal web, nanofibers, biohybrid nanoweb

\section{Introduction}

One of the main challenges of pharmaceutical technology at the beginning of the $21^{\text {st }}$ century, which is the great period of biotechnology, is the formulation of biopharmaceuticals (proteins, peptides, nucleic acids, living cells, viral particles and vaccines). These objects are generally very sensitive to the physical and chemical impacts of their environment [1]. Solid dosage forms are preferred to liquid ones from stability, dose accuracy, shipping, handling, and patientcompliance points of view; however, drying is a limiting factor in their formulation. After the biotechnological processes, gentle removal of the com- monly applied water would be desirable to keep the structure of bio-drugs unaltered [2].

Electrospinning (electrostatic spinning, ES) is a remarkably simple and efficient technique to generate fine polymeric fibers in submicron - and nano scale from polymer solutions (or melts) using high electric voltage [3]. Electrospinning provides an extremely rapid (less than $0.1 \mathrm{~s}$ [4]) and very gentle drying step at ambient temperature due to the direct interactions between the electrostatic energy and the working fluids and to the huge surface area of the fluid jets during the bending and whipping processes. This fiber forming process has been primarily devel-

\footnotetext{
${ }^{*}$ Corresponding author, e-mail: istvanwagner@gmail.com

(C) BME-PT
} 
oped in the textile industry [5-8], but in the recent years, applications have been published also in various biomedical fields such as wound dressing [9], wound healing [10], sterile filtration [11], tissue engineering $[12,13]$ and drug delivery [14-19].

In former studies bioactive ingredients such as proteins and DNA have been embedded successfully in nanofibers mainly for tissue engineering purposes, while living prokaryotic cells were encapsulated by this technique mainly for industrial application in bioreactors utilizing their metabolic activity [2022]. Zussman [23] has recently reviewed the preparation methods of electrospun polymer fibers encapsulating cells and their potential applications. Salalha et al. [24] showed that Escherichia coli and Staphylococcus albus remained viable after electrospinning process and retained their viability in polyvinyl alcohol (PVA) matrix for at least 3 months when the bacteria-containing electrospun webs were stored at -20 and $-55^{\circ} \mathrm{C}$. Lopez-Rubio et al. [25] incorporated living probiotic bacteria (B. animalis Bb12) into PVA nanofibers applying co-electrospinning and the cells remained viable after 40 days at room temperature and 130 days at 4 and $-20^{\circ} \mathrm{C}$ under refrigeration. Henceforth they encapsulated B. animalis Bb12 into protein- and carbohydrate-based microcapsules using electrospraying [26]. Similarly, Heunis et al. [27] and Fung et al. [28] embedded Lactobacillus bacteria into polymer nanofibers with moderate survival rate (2\% [27] and $1-10 \%$ [28]).

Lactobacillus acidophilus is one of the most widely investigated and used species especially in the field of dairy industry and it is an important part of normal human bacterial flora usually located in mouth, gastrointestinal tract and the urinary and genital tract of females [29, 30]. The most common vaginal disease (at ages 14-49), the bacterial vaginosis (polymicrobial syndrome caused by an imbalance of normal vaginal micro flora) is in connection with the lack of Lactobacillus bacteria and its substitution by exogenous bacteria [31]. Vaginal $\mathrm{pH}$ rises up over 4.5 during bacterial vaginosis and Lactobacillus bacteria may disappear almost completely [32]. Curing of this disorder is a considerable challenge of the healthcare worldwide because about one third of females are affected (29\% in the United States [33]). In normal vaginal microbiota, a huge number of Lactobacillus bacteria exist, which prevent the col- onization and proliferation of pathogenic microorganisms through several ways, such as competition for nutrients and adherence, production of $\mathrm{H}_{2} \mathrm{O}_{2}$ [34], bacteriocins [35] and lactic acid, which is mainly responsible for the protective acidic $\mathrm{pH}$ of the vagina [36]. Several clinical studies showed that intravaginal administration of Lactobacillus acidophilus resulted in a significantly increased number of recoveries compared to treatments with placebo, acetic acid or no treatment [37-40]. Furthermore, a recent review drew attention to the increased importance of probiotic treatment for prevention of bacterial vaginosis so that more serious complications can be avoided [41]. The efficacy of standard antibiotic treatments has been decreasing (because of the spreading of resistant bacteria strains and due to the increasing refusal of antibiotics by patients). Therefore, new, effective, readily accessible and economical lactobacilli-based probiotic therapies are badly needed [41]. It meets the purpose of this work since water-based electrospinning is a simple, scalable and continuous technology with very low energy consumption $[8,17,42]$. Furthermore, development of effective drug delivery systems for living cells and other biopharmaceuticals is a general need of pharmaceutical technology owing to the newly appearing biomedicals [43].

The aim of this work was to develop an electrospinning-based method for encapsulation of Lactobacillus acidophilus (LBA) and to investigate the applicability of electrospinning technology for preparing vaginal drug delivery systems in the form of biohybrid nanowebs (BNW) for curing of bacterial vaginosis.

\section{Experimental section \\ 2.1. Materials}

Lactobacillus acidophilus (Strain number: B1075) was kindly provided by National Collection of Agricultural and Industrial Microrganisms (Budapest, Hungary).

Polyvinyl pyrrolidone (PVP) with two different chain lengths (molecular weight: PVP K30: 50 000 Da, PVP K90: 1 200000 Da), kindly provided by BASF (Ludwigshafen, Germany) and polyvinyl alcohol (PVA), purchased from Fluka (Buchs, Switzerland, molecular weight: $130000 \mathrm{Da})$, were used as polymer matrices. Solvent was distilled water. 


\subsection{Selection of optimal concentration of polymer solution}

The optimal concentration of the polymer solutions was determined without LBA. The polymers were added into $10 \mathrm{~mL}$ of purified water and stirred by ARE magnetic stirrer (VELP Scientifica, Usmate, Italy) at $600 \mathrm{rpm}$ and $50^{\circ} \mathrm{C}$ until complete dissolution was achieved. The mass percents of polymer solutions were as follows: PVA 130000 and PVP K90: 5, 10, 15, 20\%; PVP K30: 20, 25, 30, 35, 40, $45,50 \%$. The solutions and the collected electrospun materials were investigated with a rheometer, and by optical and electron microscopy, respectively.

\subsection{Preparation of bacterial suspensions and bacteria-containing polymer suspensions}

Stock culture was subcultured in MRS agar (LabM, Bury, United Kingdom). The MRS agar was freshly prepared and sterilized. According to the instructions of the manufacturer $70 \mathrm{~g}$ of MRS agar powder was added to $1 \mathrm{~L}$ of deionized water. The system was heated and mixed properly and after total dissolution it was autoclaved at $121^{\circ} \mathrm{C}$. In each experiment, the bacteria were harvested from the surface of 3 MRS agar cultures, with approx. $5 \mathrm{~mL}$ of sterilized water, and were dispersed properly with a Vortex mixer. $5 \mathrm{~mL}$ of bacterial suspension was added to $10 \mathrm{~g}$ (1.5 g PVA, $8.5 \mathrm{~g}$ dist. water) of aqueous PVA solution and $5 \mathrm{~g}$ (2.2 g PVP K90, $3.8 \mathrm{~g}$ dist. water) of aqueous PVP K90 solution. In the case of PVP $\mathrm{K} 30$, the polymer (2.25 g) was added directly to the bacterial suspension $(3 \mathrm{~mL})$. Hereinafter they were mixed properly with magnetic stirrer at $600 \mathrm{rpm}$ and room temperature. The polymer concentrations of the obtained suspensions were as follows: PVA: 10 w/w\%, PVP K90: 20 w/w\%, PVP K30: 45 w/w\%.

\subsection{Electrospinning}

The electrostatic spinner used for the experiments was equipped with NT-35 High Voltage DC Supply (MA2000, Nagykanizsa, Hungary). The utilized electrical potential on the spinneret electrode was $35 \mathrm{kV}$, which was adjusted during the experiments. A grounded steel plate covered with polytetrafluoroethylene was used as collector. Polymer solutions were dosed by SEP-10S Plus syringe pump (Aitecs, Vilnius, Lithuania). The distance between the spinneret and the collector was $15 \mathrm{~cm}$ in all cases and the experiments were performed at room temperature $\left(25^{\circ} \mathrm{C}\right)$. Electrospinning was carried out in fume hood. The continuous ventilation provided constant humidity during the process owing to the same inlet air. Relative humidity was around $35 \%$, temperature was $25^{\circ} \mathrm{C}$.

\subsection{Rheological measurements}

Viscosity of the solutions was determined using an AR 2000 rotational rheometer (TA Instruments, New Castle, USA) in parallel plate configuration. The upper moving plate of $40 \mathrm{~mm}$ diameter and the lower Peltier plate, which adjusted the temperature of the solutions to $25^{\circ} \mathrm{C}$, were made of stainless steel.

The viscosities were measured at torques increasing logarithmically from 10 to $1000 \mu \mathrm{Nm} \cdot \mathrm{Pa}$. The shown viscosities are the averages of 10 measured values at different torques (no significant changes were estimated as a function of torque).

\subsection{Scanning electron microscopy (SEM)}

Morphology of the samples was investigated with a JEOL 6380LVa (JEOL, Japan) type scanning electron microscope. Each specimen was fixed by conductive double sided carbon adhesive tape and sputtered by gold (using a JEOL 1200 instrument).

\subsection{Viability test}

In order to determine the number of colony forming units in the prepared nanowebs and in the initial solutions of electrospinning after $4 \mathrm{~h}$, their weighed pieces were dissolved completely using $5 \mathrm{~mL}$ of sterilized water (stock solution). Hereinafter these initial solutions were diluted in nine steps $(1 \mathrm{step}=$ 10-fold dilution) and after each step $1 \mathrm{~mL}$ of solution was pipetted onto MRS agar plate. Agar plates were kept in a lockup plastic box containing activated Microbiology Anaerocult ${ }^{\mathbb{R}}$ (Merck, Darmstadt, Germany), which provides anaerobic circumstances by adsorption of oxygen. These were held at $37^{\circ} \mathrm{C}$ for 48 hours then the formed colonies were enumerated (colony forming unit $=\mathrm{CFU}$ ). $\mathrm{CFU}$ number of $1 \mathrm{~g}$ of initial solution was calculated as $100 \%$.

\subsection{Storage test}

Samples containing LBA were kept in lockup containers at the typically used storage temperatures (7, $20^{\circ} \mathrm{C}$ ), what correspond to the temperatures of a freezer and a fridge respectively. Viability of LBA bacteria in the nanofibers was investigated during the storage period (3 months) and CFU/g was determined. The method applied to determine cell viabil- 
ity was the plating procedure described in the Viability test part.

\subsection{Dissolution test}

In order to determine the release time of LBA from each nanoweb, $100 \mathrm{mg}$ of them were dissolved in $10 \mathrm{~mL}$ of dist water. Dissolution vessels were shaken with a speed of $50 \mathrm{rpm}$. After 1, 2, 3, 5, 10 and $60 \mathrm{~min}, 1 \mathrm{~mL}$ of the solution was pipetted to an MRS agar plate and the dissolution media was refilled with dist. water. The method of plating procedure was the same that described above. Dissolution was calculated as follows: the CFU number at different time points was divided by the total CFU number at the end of the dissolution test, which was considered as $100 \%$. The release from membranes was measured with three samples in each case, and the relative standard deviations were below $5 \%$.

\section{Results and discussion}

At first, the electrospinning process of polymers was optimized without bacteria and the collected dried products were investigated by SEM. Bacteria containing polymer solutions were prepared at the determined optimal concentration. The effect of the polymers on the viability of the bacteria was examined as a function of time through $4 \mathrm{~h}$ at $25^{\circ} \mathrm{C}$. After that bacteria containing polymer solutions were electrospun. The obtained morphology was investigated by SEM; the survival rate of the bacteria was quantified by viability tests. Storage tests of the electrospun products were also accomplished at two different temperatures through 3 months.

\subsection{Optimization of polymer concentration}

Before the encapsulation of LBA, the optimal concentrations of polymers in the solution to feed for electrospinning were determined. The polymers applicable for pharmaceutical purposes are limited by stringent regulations. Three different FDA approved water-soluble polymer types were applied and compared in this study (PVA, PVP K30 and PVP K90).

Logarithm of the viscosities of the examined polymer solutions increased nearly linearly with polymer concentration because of the increasing polymerpolymer interaction and the growing number of entanglements [44-46] (Figure 1). The collected solid particles and fibrous structures were investigated by scanning electron microscopy. Figure 1 refers to

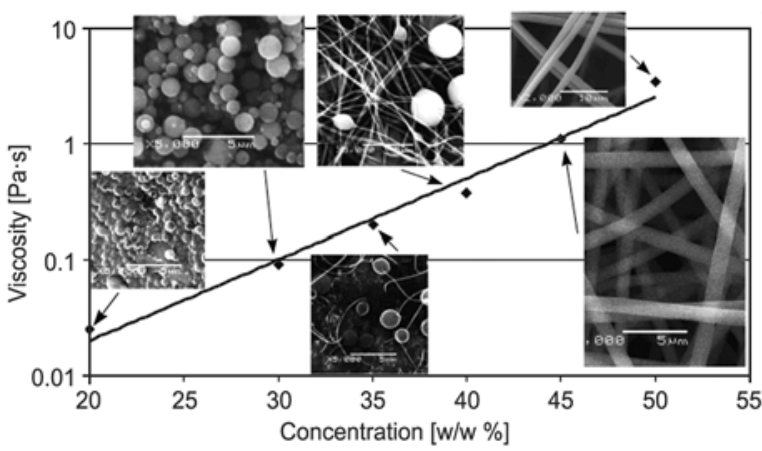

Figure 1. Viscosities of the PVP K30 of the aqueous solutions and the obtained morphology of objects electrospun from those solutions

PVP K30 showing how the morphology changed from micro- and nanoparticles through beaded fibers to nanofibers when the concentration and the viscosity of the polymer solution was varied. At lower (20-30\%) polymer concentrations, electrospraying occurred typically producing submicronic. Electrospraying has also capability to encapsulate of biodrugs in a very gentle way, which is, however, out of the scope of this paper.

Beaded fibers were gained from the 35 and $40 \mathrm{w} / \mathrm{w} \%$ solution of PVP K30, while at higher concentrations (45 and $50 \mathrm{w} / \mathrm{w} \%$ ) discrete nano- and microfibers ( $\sim 400-2000 \mathrm{~nm}$ ) were formed owing to the increased viscosity and higher entanglement of the polymer chains. Thus, $45 \mathrm{w} / \mathrm{w} \%$ polymer solution was chosen for the encapsulation of bacteria in the case of PVP K30.

When the other two polymers were used, the phenomena were similar as in the case of PVP K30 (Figure 1). At lower concentrations, beaded fibers were gained and the concentrations, which were found to be optimal for getting discrete fibers with stable structure were as follows: $10 \mathrm{w} / \mathrm{w} \%$ in the case of PVA and $20 \mathrm{w} / \mathrm{w} \%$ in the case of PVP K90. Diameters of the formed fibers at the optimal con-

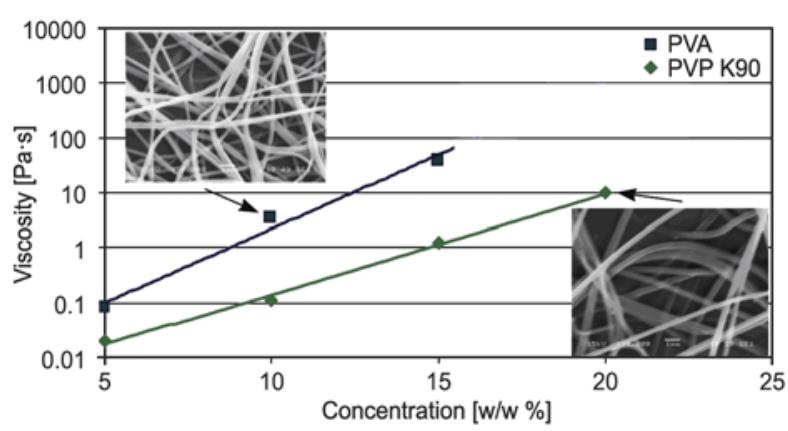

Figure 2. Viscosities of the PVA and PVP K90 aqueous solutions and the obtained morphology at the concentrations chosen for the encapsulation of bacteria 
centrations were between 150 and $350 \mathrm{~nm}$ and 200 and $600 \mathrm{~nm}$ in the cases of PVA and PVP K90, respectively (Figure 2).

\subsection{Encapsulation of Lactobacillus acidophilus into polymer nanofibers}

Encapsulation of bacteria was supposed to cause a significant change in the rheological properties of the polymer solutions. Consequently, the experiments for encapsulation were started with polymer concentration at lowest concentration in order to maintain spinnability.

In contrast to the mentioned concern, the presence of bacteria in the pumped liquids containing $10 \mathrm{w} / \mathrm{w} \%$ PVA and $45 \mathrm{w} / \mathrm{w} \%$ PVP K30 did not cause any remarkable changes in the viscosity (increasing of viscosity was below 0.1 and $0.5 \%$, respectively), only in the case of $20 \mathrm{w} / \mathrm{w} \%$ PVP K90 was 3\% difference observed. However it did not affect the fiber formation during the electrospinning process. The morphology of the LBA bacteria and their arrangement in electrospun fibers was investigated by scanning electron microscopy. Figure 3 shows the formed fibers in different magnifications. These SEM images enable us to see that the polymer fibers got thicker by encompassing rod-shaped single or interconnected bacteria. In all cases polymer coating was formed around bacteria as a result of the ES process. On the SEM images (Figures 3-6) the sizes of bacteria can be seen, which is similar to that of their original form (width: $\sim 0.5-0.7 \mu \mathrm{m}$, length: $\sim 1-$ $3 \mu \mathrm{m}$ ) that are shown in Figure 6. These results demonstrate that all the studied pharma-polymers are capable to encapsulate LBA probiotic bacteria

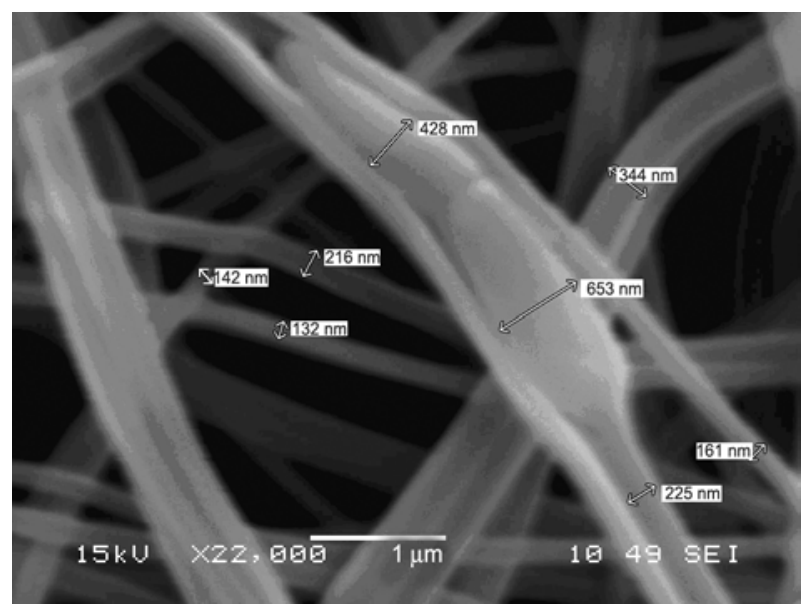

Figure 3. SEM image of LBA embedded in PVA nanofibers with thickness data into water-soluble nanofibers by electrospinning technique.

Here, the concept of electrospun living bacteria solid dosage forms containing living bacteria was put forward using a single fluid electrospinning of

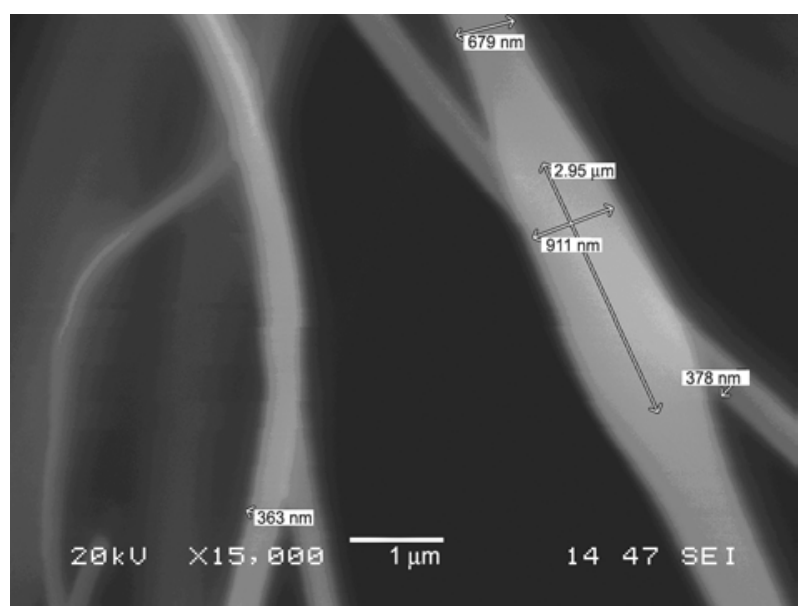

Figure 4. SEM image of LBA embedded in PVP K30 nanofibers with thickness data

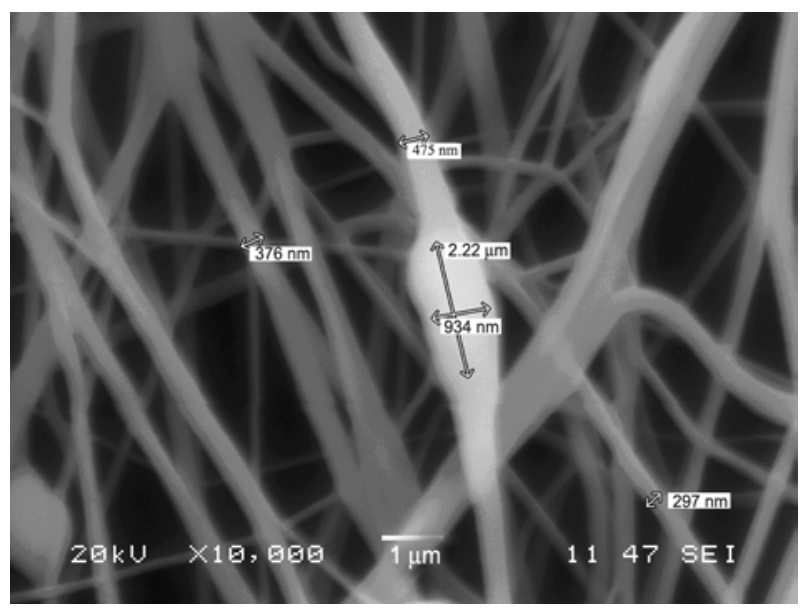

Figure 5. SEM image of LBA embedded in PVP K90 nanofibers with thickness data

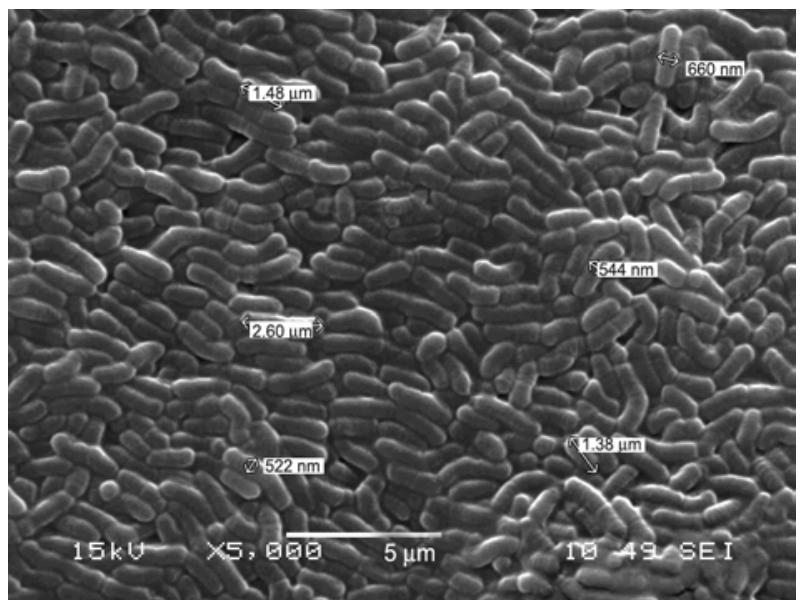

Figure 6. SEM image of the applied bacteria with thickness and length data 
suspensions. Coaxial electrospinning [47-49] could further expand this concept owing to its capability to manipulate nanostructure.

\subsection{Viability results}

As the most important issue, from the point of view of medical application, is the biological activity of LBA the living bacteria content of the nanofibers was examined after their dissolution from nanofibers.

Measurement of CFU (colony forming unit) was performed in order to determine the effect of technology steps of the whole $E S$ process on bacteria.

Immediately after electrospinning $1 \mathrm{~g}$ of nanofibers still contained large number of active LBA (from 8.78-9.28 $\log$ CFU) as the survival rate of the bacteria was between 34 and $68 \%$ (Table 1.), which is a remarkable result compared to efficiency of current drying processes such as freeze drying and spray drying. As Rybka and Kailasapathy [50] reported that recovery of viable Lactobacillus acidophilus cells after freeze drying was between $1-56 \%$ as a percentage of cells in the original solution. Besides, Riveros et al. [51] and Wang et al. [52] spray dried Lactobacillus acidophilus under gentle conditions (inlet temperature: $100^{\circ} \mathrm{C}$, outlet temperature: 58 , $60^{\circ} \mathrm{C}$ ). Nevertheless, survival rates were only 11 and $4.9 \%$ respectively. The better survival rate in

Table 1. Number of active bacteria and survival rate in different types of electrospun nanowebs

\begin{tabular}{|l|c|c|c|}
\hline & $\begin{array}{c}\text { Initial solution } \\
\log (\mathbf{C F U} / \mathbf{g})\end{array}$ & $\begin{array}{c}\text { Electrospun } \\
\text { biohybrid nanoweb } \\
\log (\mathbf{C F U} / \mathbf{g})\end{array}$ & $\begin{array}{c}\text { Survival } \\
{[\%]}\end{array}$ \\
\hline PVA & $9.45 \pm 0.03$ & $9.28 \pm 0.03$ & 68 \\
\hline PVP K30 & $9.12 \pm 0.04$ & $8.65 \pm 0.04$ & 34 \\
\hline PVP K90 & $9.18 \pm 0.03$ & $8.78 \pm 0.04$ & 40 \\
\hline
\end{tabular}

case of PVA can be explained by the oxygen excluding property of this polymer, which means that the bacteria are protected during the process [53].

Viability of LBA bacteria in polymer-containing suspensions without electrospinning process was investigated at ambient temperature as a reference. Number of CFU after $4 \mathrm{~h}$ decreased to 79, 72 and $70 \%$ (data are not shown) of the initial number in PVA-, PVP K30- and PVP K90-containing suspensions, respectively. This phenomenon is probably due to the lack of nutritive in the suspensions and can be avoided by adding nutrients and stabilizers to the solution.

Based on these findings electrospinning is a capable technique to produce solid dosage form of LBA in a gentle way.

\subsection{Stability results}

Table 2 presents the result of stability tests in case of three different of polymers. Keeping samples at ambient temperature caused the total loss of biological activity of them after a week (data are not shown). This result was predictable because marketed biopharmaceutical products containing living organism have to be stored generally at $2-8^{\circ} \mathrm{C}$. The difference between the stability of samples stored at 7 and $-20^{\circ} \mathrm{C}$ is very slight suggesting that both storage conditions are applicable and freezing is probably not necessary in most cases. Stability tests also confirmed that all of the selected polymer solutions, having no significant effect on viability of LBA, are applicable for living cell formulation. After 90 days, nanofibers still contained large amounts of LBA, which is a remarkable achievement considering the fact that there was no stabilizer of LBA present.

Table 2. Number of colony forming units per grams of electrospun nanofibers as a function of time at two temperatures

\begin{tabular}{|c|c|c|c|c|c|}
\hline & & \multicolumn{4}{|c|}{$\begin{array}{c}\text { Time } \\
\text { [days] }\end{array}$} \\
\hline & & $\mathbf{0}$ & 7 & 30 & 90 \\
\hline \multirow{2}{*}{$\operatorname{PVA}\left(7^{\circ} \mathrm{C}\right)$} & $\log (\mathrm{CFU} / \mathrm{g})$ & $9.28 \pm 0.03$ & $8.72 \pm 0.02$ & $8.34 \pm 0.03$ & $7.97 \pm 0.05$ \\
\hline & $\%$ & 100 & 27 & 11 & 4,9 \\
\hline \multirow{2}{*}{$\operatorname{PVA}\left(-20^{\circ} \mathrm{C}\right)$} & $\log (\mathrm{CFU} / \mathrm{g})$ & $9.28 \pm 0.03$ & $8.49 \pm 0.03$ & $8.29 \pm 0.05$ & $8.09 \pm 0.03$ \\
\hline & $\%$ & 100 & 16 & 10 & 6,4 \\
\hline \multirow{2}{*}{ PVP K30 $\left(7^{\circ} \mathrm{C}\right)$} & $\log (\mathrm{CFU} / \mathrm{g})$ & $8.65 \pm 0.04$ & $7.94 \pm 0.06$ & $7.55 \pm 0.04$ & $7.07 \pm 0.04$ \\
\hline & $\%$ & 100 & 19 & 7,9 & 2,6 \\
\hline \multirow{2}{*}{ PVP K30 $\left(-20^{\circ} \mathrm{C}\right)$} & $\log (\mathrm{CFU} / \mathrm{g})$ & $8.65 \pm 0.04$ & $8.28 \pm 0.04$ & $7.88 \pm 0.03$ & $7.58 \pm 0.03$ \\
\hline & $\%$ & 100 & 42 & 17 & 8,5 \\
\hline \multirow{2}{*}{ PVP K90 $\left(7^{\circ} \mathrm{C}\right)$} & $\log (\mathrm{CFU} / \mathrm{g})$ & $8.78 \pm 0.04$ & $8.11 \pm 0.03$ & $7.72 \pm 0.06$ & $7.24 \pm 0.05$ \\
\hline & $\%$ & 100 & 21 & 8,8 & 2,9 \\
\hline \multirow{2}{*}{ PVP K90 $\left(-20^{\circ} \mathrm{C}\right)$} & $\log (\mathrm{CFU} / \mathrm{g})$ & $8.78 \pm 0.04$ & $8.35 \pm 0.05$ & $7.95 \pm 0.03$ & $7.64 \pm 0.04$ \\
\hline & $\%$ & 100 & 37 & 14 & 7.2 \\
\hline
\end{tabular}


Applying stabilizer and packaging that excludes the oxygen would probably further improve the stability of living LBA [54].

\subsection{Potential dosage forms of LBA containing biohybrid nanoweb}

Industrial scaling-up of the described process seems to be achievable based on recent developments in the field of electrospinning. Several solutions for industrial-scale production of electrospun nanofibers are available and used mainly in the filtration industry [55]. Industrially performed electrospinning, equipped with transferring collector, is continuous process having very low energy consumption and high enough capacity to fabricate pharmaceutical products. As the developed electrospun BNW contain, according to the viability and stability results, high enough amounts of biologically active probiotic bacteria, several novel and existing pharmaceutical dosage forms can be designed on this basis. PVA and PVP have already been applied in vaginal formulations [56]; thus, vaginal film or electrospun biohybrid nanoweb of these polymers, containing LBA, can easily get approval from the authorities.

In order to use the new living-cell-containing solid materials for curing bacterial vaginosis, selection of administration in adequate form is also necessary. The simplest way is to apply the prepared nonwoven tissue directly after the removal from the collector and cutting into proper-sized (proper-weight) pieces. The square-cut webs can be delivered manually into the vagina (similarly to the insertion of vaginal contraceptive films called VCF), where the inserted web dissolves. For this kind of administration PVA- and PVP K90-based biohybrid nanowebs with mucoadhesive character $[57,58]$ are preferred and some kind of applicator (tweezers, protective gloves, etc.) needs to avoid the dissolution of web before placement. These nanofibrous tissues can be attached to a carrier film containing enhancer additives. The multilayer system, adhered to the mucosa, releases the bacteria as the polymer dissolves.

Furthermore, all kinds of nanowebs prepared in this work, dissolved instantly when they got in contact with water, and can be well exploited in stabile formulation. On Figure 7 saturation curves show that nearly the total $(90 \%)$ amount of bacteria were released within one minute and there was no signif-

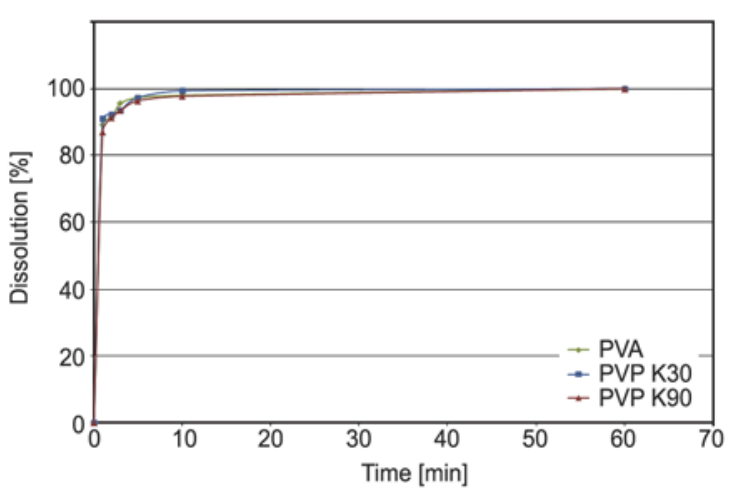

Figure 7. Release of LBA from different polymers (PVA, PVP K30, PVP K90) based BNWs

icant difference between the polymers due to the huge surface and to the good solubility of nanofibers.

After the rapid dissolution of the solid BNW, the obtained LBA-containing liquid is administrable as a douche and can be effective against bacterial vaginosis owing to the high active probiotic content. Further enhancement of curing efficiency can be achieved by introducing appropriate excipients such as lactose, lactic acid and buffering salts, in the solvent of the web. As the nanofibrous matrix dissolves instantly when contacting with water, it can also be filled in disposable syringes together with excipients, buffering agents and enhancers which can be injected after rapid dissolution in water loaded in the syringe.

\section{Conclusions}

The present work shows that electrospinning is a capable way for stable solid formulation of LBA. It was found that with all the three studied polymers solutions were suitable for encapsulating huge amounts of LBA and provided long shelf life at 7 and $20^{\circ} \mathrm{C}$, which can be even further extended using stabilizer excipients or applying oxygen excluding packaging. The formed nanofibrous product can be applied as an inexpensive and easy-to-use dosage form that can be recommended for the treatment of bacterial vaginosis. An adequate dose of living bacteria could be stabilized using this effective and gentle technique, which is considered to be a feasible way to produce other biopharmaceuticals as well. The dosage forms (e.g. vaginal douche) based on the developed biohybrid nanowebs are new potential way for curing bacterial vaginosis. 


\section{Acknowledgements}

This project was financially supported by the New Széchenyi Development Plan (project ID: TÁMOP-4.2.1/B-09/1/ KMR-2010-0002) and the Hungarian Research Fund (OTKA PD-108975, OTKA K 100949). The authors would like to express their special thanks to Richter Gedeon Talentum foundation for their generous support of István Wagner's scholarship.

\section{References}

[1] Parkins D. A., Lashmar U. T.: The formulation of biopharmaceutical products. Pharmaceutical Science and Technology Today, 3, 129-137 (2000). DOI: $10.1016 / \mathrm{S} 1461-5347(00) 00248-0$

[2] Maa Y-F., Prestrelski S. J.: Biopharmaceutical powders particle formation and formulation considerations. Current Pharmaceutical Biotechnology, 1, 283-302 (2000).

DOI: $\underline{10.2174 / 1389201003378898}$

[3] Greiner A., Wendorff J. H.: Electrospinning: A fascinating method for the preparation of ultrathin fibers. Angewandte Chemie International Edition, 46, 5670-5703 (2007).

DOI: 10.1002/anie.200604646

[4] Liu Y. Y., Li Q. W., Hu Q. X., Jing C. J., Wang Q. G.: A new spurts controllable electrospinning collecting device designed basing on advanced motion control. Applied Mechanics and Materials, 44-47, 1698-1702 (2011).

DOI: $10.4028 /$ www.scientific.net/AMM.44-47.1698

[5] Lukáš D., Sarkar A., Martinová L., Vodsed’álková K., Lubasová D., Chaloupek J., Pokorný P., Mikeš P., Chvojka J., Komárek M.: Physical principles of electrospinning (electrospinning as a nano-scale technology of the twenty-first century). Textile Progress, 41, 59-140 (2009).

DOI: $10.1080 / 00405160902904641$

[6] Molnár K., Vas L. M., Czigány T.: Determination of tensile strength of electrospun single nanofibers through modeling tensile behavior of the nanofibrous mat. Composites Part B: Engineering, 43, 15-21 (2012). DOI: $10.1016 /$ j.compositesb.2011.04.024

[7] Yu D. G., Branford-White C., White K., Chatterton N. P., Zhu L. M., Huang L. Y., Wang B.: A modified coaxial electrospinning for preparing fibers from a high concentration polymer solution. Express Polymer Letters, 5, 732-741 (2011).

DOI: 10.3144/expresspolymlett.2011.71

[8] Koštáková E., Mészáros L., Gregr J.: Composite nanofibers produced by modified needleless electrospinning. Materials Letters, 63, 2419-2422 (2009). DOI: 10.1016/j.matlet.2009.08.014

[9] Rosic R., Kocbek P., Baumgartner S., Kristl J.: Electro-spun hydroxyethyl cellulose nanofibers: The relationship between structure and process. Journal of Drug Delivery Science and Technology, 21, 229-236 (2011).
[10] Rho K. S., Jeong L., Lee G., Seo B-M., Park Y. J., Hong S-D., Roh S., Cho J. J., Park W. H., Min B-M.: Electrospinning of collagen nanofibers: Effects on the behavior of normal human keratinocytes and earlystage wound healing. Biomaterials, 27, 1452-1461 (2006).

DOI: 10.1016/j.biomaterials.2005.08.004

[11] Huang F., Wang Q., Wei Q., Gao W., Shou H., Jiang S.: Dynamic wettability and contact angles of poly(vinylidene fluoride) nanofiber membranes grafted with acrylic acid. Express Polymer Letters, 4, 551-558 (2010). DOI: $10.3144 /$ expresspolymlett.2010.69

[12] Sun K., Li Z. H.: Preparations, properties and applications of chitosan based nanofibers fabricated by electrospinning. Express Polymer Letters, 5, 342-361 (2011). DOI: 10.3144/expresspolymlett.2011.34

[13] Rampichová M., Martinová L., Košt’áková E., Filová E., Míčková A., Buzgo M., Michálek J., Přádný M., Nečas A., Lukáš D., Amler E.: A simple drug anchoring microfiber scaffold for chondrocyte seeding and proliferation. Journal of Materials Science: Materials in Medicine, 1, 555-563 (2012). DOI: $10.1007 / \mathrm{s} 10856-011-4518-\mathrm{X}$

[14] Verreck G., Chun I., Peeters J., Rosenblatt J., Brewster M. E.: Preparation and characterization of nanofibers containing amorphous drug dispersions generated by electrostatic spinning. Pharmaceutical Research, 20, 810-817 (2003). DOI: 10.1023/A:1023450006281

[15] Yu D-G., Liu F., Cui L., Liu Z-P., Wang X., Bligh S. W. A.: Coaxial electrospinning using a concentric Teflon spinneret to prepare biphasic-release nanofibers of helicid. RSC Advances, 3, 17775-17783 (2013). DOI: 10.1039/C3RA43222J

[16] Yu D-G, Branford-White C., White K., Li X-L., Zhu L-M.: Dissolution improvement of electrospun nanofiber-based solid dispersions for acetaminophen. AAPS PharmSciTech, 11, 809-817 (2010). DOI: $10.1208 / \mathrm{s} 12249-010-9438-4$

[17] Nagy Zs. K., Nyúl K., Wagner I., Molnár K., Marosi Gy.: Electrospun water soluble polymer mat for ultrafast release of Donepezil HCl. Express Polymer Letters, 4, 763-772 (2010).

DOI: $10.3144 /$ expresspolymlett.2010.92

[18] Yu D-G., Yu J-H., Chen L., Williams G. R., Wang X.: Modified coaxial electrospinning for the preparation of high-quality ketoprofen-loaded cellulose acetate nanofibers. Carbohydrate Polymers, 90, 1016-1023 (2012).

DOI: 10.1016/j.carbpol.2012.06.036

[19] Nagy Zs. K., Balogh A., Vajna B., Farkas A., Patyi G., Kramarics Á., Marosi Gy.: Comparison of electrospun and extruded soluplus ${ }^{\circledR}$-based solid dosage forms of improved dissolution. Journal of Pharmaceutical Sciences, 101, 322-332 (2011).

DOI: $10.1002 / j p s .22731$ 
[20] Liu Y., Rafailovich M. H., Malal R., Cohn D., Chidambaram D.: Engineering of bio-hybrid materials by electrospinning polymer-microbe fibers. Proceedings of the National Academy of Sciences, 106, 1420114206 (2009).

DOI: 10.1073/pnas.0903238106

[21] Klein S., Kuhn J., Avrahami R., Tarre S., Beliavski M., Green M., Green M., Zussman E.: Encapsulation of bacterial cells in electrospun microtubes. Biomacromolecules, 10, 1751-1756 (2009).

DOI: $10.1021 / \mathrm{bm} 900168 \mathrm{v}$

[22] Gensheimer M., Becker M., Brandis-Heep A., Wendorff J. H., Thauer R. K., Greiner A.: Novel biohybrid materials by electrospinning: Nanofibers of poly(ethylene oxide) and living bacteria. Advanced Materials, 19, 2480-2482 (2007).

DOI: $10.1002 /$ adma.200602936

[23] Zussman E.: Encapsulation of cells within electrospun fibers. Polymers for Advanced Technologies, 22, 366371 (2011).

DOI: $10.1002 /$ pat.1812

[24] Salalha W., Kuhn J., Dror Y., Zussman E.: Encapsulation of bacteria and viruses in electrospun nanofibres. Nanotechnology, 17, 4675-4681 (2006).

DOI: 10.1088/0957-4484/17/18/025

[25] López-Rubio A., Sanchez E., Sanz Y., Lagaron J. M.: Encapsulation of living bifidobacteria in ultrathin $\mathrm{PVOH}$ electrospun fibers. Biomacromolecules, 10, 2823-2829 (2009).

DOI: $10.1021 / \mathrm{bm} 900660 \mathrm{~b}$

[26] López-Rubio A., Sanchez E., Wilkanowicz S., Sanz Y., Lagaron J. M.: Electrospinning as a useful technique for the encapsulation of living bifidobacteria in food hydrocolloids. Food Hydrocolloids, 28, 159-167 (2012). DOI: $10.1016 /$ j.foodhyd.2011.12.008

[27] Heunis T. D. J., Botes M., Dicks L. M. T.: Encapsulation of Lactobacillus plantarum 423 and its bacteriocin in nanofibers. Probiotics and Antimicrobial Proteins, 2, 46-51 (2010). DOI: $10.1007 / \mathrm{s} 12602-009-9024-9$

[28] Fung W-Y., Yuen K-H., Liong M-T.: Agrowaste-based nanofibers as a probiotic encapsulant: Fabrication and characterization. Journal of Agricultural and Food Chemistry, 59, 8140-8147 (2011). DOI: $10.1021 /$ jf2009342

[29] Cannon J., Lee T., Bolanos J., Danziger L.: Pathogenic relevance of Lactobacillus: A retrospective review of over 200 cases. European Journal of Clinical Microbiology and Infectious Diseases, 24, 31-40 (2005). DOI: 10.1007/s10096-004-1253-y

[30] Madigan M. T.: Prokaryotic diversity: The bacteria. in 'Brock biology of microorganisms' (eds: Madigan M. T., Martinko J. M., Stahl D., Clark D. P.) Prentice Hall, Upper Saddle River, USA' 329-418 (2006).

[31] Castellano Filho D. S., Diniz C. G., Silva V. L.: Bacterial vaginosis: Clinical, epidemiologic and microbiological features. HU Revista, 36, 223-230 (2010).
[32] Mastromarino P., Macchia S., Meggiorini L., Trinchieri V., Mosca L., Perluigi M., Midulla C.: Effectiveness of Lactobacillus-containing vaginal tablets in the treatment of symptomatic bacterial vaginosis. Clinical Microbiology and Infection, 15, 67-74 (2009). DOI: $10.1111 / \mathrm{j} .1469-0691.2008 .02112 . \mathrm{x}$

[33] Allsworth J. E., Peipert J. F.: Prevalence of bacterial vaginosis: 2001-2004 national health and nutrition examination survey data. Obstetrics and Gynecology, 109, 114-120 (2007). DOI: 10.1097/01.AOG.0000247627.84791.91

[34] McLean N. W., McGroarty J. A.: Growth inhibition of metronidazole-susceptible and metronidazole-resistant strains of Gardnerella vaginalis by Lactobacilli in vitro. Applied and Environmental Microbiology, 62, 1089-1092 (1996).

[35] Simoes J. A., Aroutcheva A., Heimler I., Shott S., Faro S.: Bacteriocin susceptibility of Gardnerella vaginalis and its relationship to biotype, genotype, and metronidazole susceptibility. American Journal of Obstetrics and Gynecology, 185, 1186-1190 (2001). DOI: $10.1067 / \mathrm{mob} .2001 .118144$

[36] Falagas M. E., Betsi G. I., Athanasiou S.: Probiotics for the treatment of women with bacterial vaginosis. Clinical Microbiology and Infection, 13, 657-664 (2007). DOI: $10.1111 / \mathrm{j} .1469-0691.2007 .01688 . \mathrm{x}$

[37] Hallén A., Jarstrand C., Påhlson C.: Treatment of bacterial vaginosis with Lactobacilli. Sexually Transmitted Diseases, 19, 146-148 (1992).

[38] Chimura T., Funayama T., Murayama K., Numazaki M.: Ecological treatment of bacterial vaginosis. The Japanese Journal of Antibiotics, 48, 432-436 (1995).

[39] Parent D., Bossens M., Bayot D., Kirkpatrick C., Graf F., Wilkinson F. E., Kaiser R. R.: Therapy of bacterial vaginosis using exogenously-applied Lactobacilli acidophili and a low dose of estriol: A placebo-controlled multicentric clinical trial. Arzneimittelforschung, 46, 68-73 (1996).

[40] Neri A., Sabah G., Samra Z.: Bacterial vaginosis in pregnancy treated with yoghurt. Acta Obstetricia et Gynecologica Scandinavica, 72, 17-19 (1993).

DOI: $10.3109 / 00016349309013342$

[41] MacPhee R. A., Hummelen R., Bisanz J. E., Miller W. L., Reid G.: Probiotic strategies for the treatment and prevention of bacterial vaginosis. Expert Opinion on Pharmacotherapy, 11, 2985-2995 (2010). DOI: $10.1517 / 14656566.2010 .512004$

[42] Persano L., Camposeo A., Tekmen C., Pisignano D.: Industrial upscaling of electrospinning and applications of polymer nanofibers: A review. Macromolecular Materials and Engineering, 298, 504-520 (2013). DOI: $10.1002 /$ mame. 201200290 
[43] Park S. J., Park S-H., Cho S., Kim D-M., Lee Y., Ko S. Y., Hong Y., Choy H. E., Min J-J., Park J-O., Park S.: New paradigm for tumor theranostic methodology using bacteria-based microrobot. Scientific Reports, 3, 3394/1-3394/8 (2013).

DOI: $10.1038 /$ srep03394

[44] Shenoy S. L., Bates W. D., Frisch H. L., Wnek G. E.: Role of chain entanglements on fiber formation during electrospinning of polymer solutions: Good solvent, non-specific polymer-polymer interaction limit. Polymer, 46, 3372-3384 (2005).

DOI: 10.1016/j.polymer.2005.03.011

[45] Zeng J., Haoqing H., Schaper A., Wandorff J. H., Greiner A.: Poly-L-lactide nanofibers by electrospinning - Influence of solution viscosity and electrical conductivity on fiber diameter and fiber morphology. e-Polymers, no.009 (2005).

[46] Beachley V., Wen X.: Effect of electrospinning parameters on the nanofiber diameter and length. Materials Science and Engineering: C, 29, 663-668 (2009). DOI: $10.1016 / \mathrm{j} . \mathrm{msec} .2008 .10 .037$

[47] Yu D. G., Wang X., Li X. Y., Chian W., Li Y., Liao Y. Z.: Electrospun biphasic drug release polyvinylpyrrolidone/ethyl cellulose core/sheath nanofibers. Acta Biomaterialia, 9, 5665-5672 (2012).

DOI: $10.1016 /$ j.actbio.2012.10.021

[48] Yu D-G., Williams G. R., Wang X., Liu X-K., Li H-L., Bligh S. W. A.: Dual drug release nanocomposites prepared using a combination of electrospraying and electrospinning. RSC Advances, 3, 4652-4658 (2013). DOI: $10.1039 / C 3 R A 40334 C$

[49] Yu D-G., Li X-Y., Wang X., Chian W., Liao Y-Z., Li Y.: Zero-order drug release cellulose acetate nanofibers prepared using coaxial electrospinning. Cellulose, 20, 379-389 (2013).

DOI: $10.1007 / \mathrm{s} 10570-012-9824-\mathrm{Z}$

[50] Rybka S., Kailasapathy K.: The survival of culture bacteria in fresh and freeze-dried AB yoghurts. Australian Journal of Dairy Technology, 50, 51-57 (1995).
[51] Riveros B., Ferrer J., Bórquez R.: Spray drying of a vaginal probiotic strain of Lactobacillus acidophilus. Drying Technology, 27, 123-132 (2009).

DOI: $10.1080 / 07373930802566002$

[52] Wang Y-C., Yu R-C., Chou C-C.: Viability of lactic acid bacteria and bifidobacteria in fermented soymilk after drying, subsequent rehydration and storage. International Journal of Food Microbiology, 93, 209-217 (2004).

DOI: $10.1016 /$ j.ijfoodmicro.2003.12.001

[53] Miller K. S., Krochta J. M.: Oxygen and aroma barrier properties of edible films: A review. Trends in Food Science and Technology, 8, 228-237 (1997).

DOI: $10.1016 / \mathrm{S} 0924-2244(97) 01051-0$

[54] Morgan C. A., Herman N., White P. A., Vesey G.: Preservation of micro-organisms by drying; A review. Journal of Microbiological Methods, 66, 183-193 (2006).

DOI: 10.1016/j.mimet.2006.02.017

[55] Zhou F-L., Gong R-H., Porat I.: Mass production of nanofibre assemblies by electrostatic spinning. Polymer International, 58, 331-342 (2009).

DOI: $10.1002 /$ pi.2521

[56] Garg S., Tambwekar K. R., Vermani K., Garg A., Kaul C. L., Zaneveld L. J. D.: Compendium of pharmaceutical excipients for vaginal formulations. Pharmaceutical Technology, 25, 14-25 (2001).

[57] Perioli L., Ambrogi V., Angelici F., Ricci M., Giovagnoli S., Capuccella M., Rossi C.: Development of mucoadhesive patches for buccal administration of ibuprofen. Journal of Controlled Release, 99, 73-82 (2004).

DOI: $10.1016 /$ j.jconrel.2004.06.005

[58] Peppas N. A., Mongia N. K.: Ultrapure poly(vinyl alcohol) hydrogels with mucoadhesive drug delivery characteristics. European Journal of Pharmaceutics and Biopharmaceutics, 43, 51-58 (1997).

DOI: 10.1016/S0939-6411(96)00010-0 